Nippon Suisan Gakkaishi $\quad$ 70(5), 788-789 (2004)

\title{
ミニシンポジウム 干潟域の一次生産者〜その生態と機能〜
}

\author{
付着珪藻の生態
}

河 村 知 彦

東京大学海洋研究所

Ecology of benthic diatoms

TOMOHIKо KAWAMURA

Ocean Research Institute, The University of Tokyo, Tokyo 164-8639, Japan

付着性あるいは底生性の珪藻 (以下，付着珪藻と総称) は，干潟に扔ける主要な一次生産者である。その多くは 底泥の表層数 $\mathrm{cm}$ 以浅に生息しており ${ }^{1}$ 表層 $0-1 \mathrm{~cm}$ に おける細胞密度 $\left.\left(10^{5}-10^{7} \mathrm{cells} / \mathrm{cm}^{3}\right)^{2}\right)$ は植物プランク トンに比べて概して高い。単位面積あたりの生産力でみ ても, 付着珪藻を主体とする底生微小藻類の生産力は沿 岸域の植物プランクトンの生産力に匹敵すると考えられ ている。 ${ }^{3)}$

干潟の砂泥底に生息する付着珪藻の中には, 砂粒の表 面に比較的強く付着するものや砂の間隙を動き回るも の, 砂泥底の表面に転がっているものなど，いくつかの タイプがあり，それぞれ異なる生態を持っていると推察 される。しかし，そのいずれについてもわかっているこ とは少ない。

\section{1）付着珪藻現存量の変動要因}

付着珠藻の増殖や光合成活性には, 光強度, 水温, 塩 分，栄養塩濃度なぞが影響を及ぼし，それぞれの環境要 因に対する増殖最適範囲は種によって異なる。出) しか し, 基質上に生育する付着珪藻は, 水塊とともに移動す る浮遊珠藻に比べて, 水温や塩分など環境の変化に曝さ れる可能性が高い。潮の干満により干出する時間帯のあ る干潟では, 特に温度変化が大きく, 乾燥に曝される場 合もある。したがって，それらの環境要因に対する付着 珪藻の増殖至適域は比較的広く, ${ }^{6,7)}$ 水温や塩分の変化に よる現存量の大きな変化は起こりにくいと考えられる。 逆に，周りの水塊が移動するため栄養塩は供給されやす く, 砂泥中からも常に供給されるため, 栄養塩の不足が 干潟の付着珠藻の増殖を制限することは少ないであろ う。

一方, 海底の基質上には付着珪藻を捕食する動物が多 数生息している。これら植食動物による拱食圧は, 光条 件とともに付着珪藻の主要な増殖制限要因となってい る。 8 ,9) 付着珪藻のブルームは冬季から春季の低水温期に 見られることが多い。多くの場合, これは植食動物の摂 食圧が下がるために起こる現象と考えられる。

\section{2）付着珪藻群落の遷移}

水中に新たな裸面が形成されると，その表面には数日 のうちに細菌などとともに付着珪藻の群落が形成され る。この付着珪藻群落の構造や種組成は時間の経過とと もに遷移する。8,10,11) 岩盤上などの安定した基質上で は，付着珪藻に対する摂食圧が比較的低く，十分な光量 がある場合，増殖が速い匍甸滑走型の珪藻がまず始めに 平面的群落を形成する。その後大きな群体を形成する珪 藻が増え, 数週間のうちには三次元的群落に移行する。 群落の下層となり光環境が悪化する基質上では, 比較的 弱い光でも増殖できる付着力の強い匍甸固着型の種が徐 々に増加し, 上層の群体が脱落した後に優占して平面的 群落を形成する。12,13)

拱食圧が低い場合には，遷移の進行過程は光条件の影 響を強く受ける。匍匐滑走型の種や群体をつくる珠藻 は, 増殖に比較的強い光を必要とするため光条件が悪い 場合には増加できず，増殖に強い光を必要としない夕イ プの珪藻が初めから優占する。光条件が悪いほど匍匐固 着型の種が優占しやすくなる。

拱食圧が高い場合には, 光条件に係わらず群体を形成 する種類は増加することができない。匍甸滑走型など付 着力の弱い珪藻も掑食されやすく, 摂食圧の増加に伴い 減少する。拱食圧が高いほど, 最も食われにくい匍匐固 着型の珪藻が最初から優占する遷移過程が見られ る。 ${ }^{12,13)}$

\section{3）干潟の付着珪藻の特徵}

付着珪藻の中には, ある種の海藻や動物に特異的に付 着する種も知られているが，多くは基質を選ばずに付着 ・増殖する。しかし，干潟や砂泥底に生息する珪藻と岩 盤上に付着する珪藻の組成は，同じ場所でも大きく異な る場合がある。12,14)これは主に付着基質の安定性の違い によるものと考えられる。

砂泥底では，付着基質となる砂粒同士が頻繁に擦れ合 うものと思われる。したがって，大きな群体は発達しに くく, 三次元的群落も形成されにくい。また，砂粒の表 
面に形成された群落は剥離されやすく，比較的短時間で 遷移の始相に戻ることも多い。基質である砂粒が埋没す ることにより, 暗黒条件下に置かれることも少なくない と考えられる。このような条件の砂泥底では, 砂粒の間 隙を鉛直移動することのできる種や，遷移の始相に現れ る増殖速度の速い滑走型の種, あるいは砂粒の表面に強 固に付着し，暗黒条件下でも比較的長く生存することの できる匍匐固着型の種が優占しやすいものと考えられ る。

一方, 上述したように, 干潟などの砂泥底では栄養塩 が不足することが少なく, 付着珪藻の生産量は周年比較 的高く保たれている。また，岩礁に比べて珪藻を補食す る動物が少ないため, 現存量も年間を通じて比較的高く 安定している。付着珪藻が生産する細胞外有機物を細菌 が分解することによって始まる食物連鎖が，干潟や砂浜 域生態系に掞いて重要な役割を果たしていることも指摘 されている。15)

\section{文献}

1) MacIntyre HL, Cullen JJ. Fine-scale vertical resolution of chlorophyll and photosynthetic parameters in shallowwater benthos. Mar. Ecol. Prog. Ser. 1995; 122: 227-237.

2) MacIntyre HL, Geider RJ, Miller DC. Microphytobenthos: The ecological role of the "Secret Garden" of unvegetated, shallow water marine habitats. I. Diatribution, abundance and primary production. Estuaries 1996; 19: 186-201.

3) Charpy-Roubaud C, Sournia A. The comparative estimation of phytoplanktonic, microphytobenthic and macrophytobenthic primary production in the oceans. Mar.
Microb. Food Webs 1990; 4: 30-57.

4) Admiraal $W$, Peletier $H$. Influence of seasonal variations of temperature and light on the growth rate of cultures and natural populations of intertidal diatoms. Mar. Ecol. Prog. Ser. 1980; 2: 35-43.

5）大貝政治.のり葉体抢よびのり網に着生する珪藻の生態 に関する研究. 水大校研報 1986; 34: 37-89.

6) Williams RB. Division rates of salt marsh diatoms in relation to salinity and cell size. Ecology 1964; 45: 877-880.

7) Admiraal W. Salinity tolerance of benthic estuarine diatoms as tested with a rapid polarographic measurement of photosynthesis. Mar. Biol. 1977; 39: 11-19.

8) Hudon C, Bourget E. The effect of light on the vertical structure of epibenthic diatom communities. Bot. Mar. 1983; 26: 317-330.

9) Kawamura T, Hirano R. Seasonal changes in benthic diatom communities colonizing glass slides in Aburatsubo Bay, Japan. Diatom Res. 1992; 7: 227-239.

10) Hoagland KD, Roemer SC, Rosowski JR. Colonization and community structure of two periphyton assemblages, with emphasis on the diatoms (Bacillariophyceae). Amer. J. Bot. 1982; 69: 188-213.

11) Hudon $C$, Bourget $E$. Initial colonization of artificial substrate: community development and structure studied by scanning electron microscopy. Can. J. Fish. Aquat. Sci. 1981; 38: 1371-1384.

12) 河村知彦. 海産付着珪藻の分類と生態. 付着生物研究 1994; 10: 7-25.

13）河村知彦. 付着珪藻群落の変動機構. 月刊海洋 1995; 27: 591-596.

14）巌佐耕三.「珪藻の生物学」東京大学出版会, 東京. $1976 ; 136$.

15) Goto N, Kawamura T, Mitamura O, Terai H. Importance of extracellular organic carbon production in the total primary production by tidal-flat diatoms in comparison to phytoplankton. Mar. Ecol. Prog. Ser. 1999; 190: 289-295. 